МОДЕЛЬ УПРАВЛІННЯ ПРОФЕСІЙНО-ПЕДАГОГІЧНИМ САМОПРОЄКТУВАННЯМ МАЙБУТНІХ МЕНЕДЖЕРІВ ОСВІТИ

\title{
MODEL OF MANAGEMENT OF PROFESSIONAL-PEDAGOGICAL SELF-DESIGN FUTURE EDUCATION MANAGERS
}

Стаття присвячена актуальній проблемі підготовки майбутніх менеджерів освіти - їх профресійно-педагогічному самопроєктуванню. Зокрема, зазначається, що професійна діяльність менеджерів освіти $\epsilon$ есективною за умови наявності готовності до досягнення ними власного профресійного акме, націленості на успіх, володіння акмеологічними технологіями саморозвитку та самовдосконалення, складником яких є самопроєктування.

Для того щоб зрозуміти сутність самопроєктування, розроблено модель управління цим процесом, що являє собою гіпотезу про його розгортання та можливі результати такого процесу. Мета моделі управління професійнопедагогічним самопроєктуванням майбутніх менеджерів освіти полягає у забезпеченні успішності управління цим процесом. Досягнення мети передбачає вирішення низки завдань: 1) визначення сутності феномена «самопроєктування»; 2) аналіз методологічних підходів і принципів; 3) виявлення акмеологічних шляхів та умов самопроєктування майбутніх менеджерів освіти; 4) розробка акмеологічної технології як засобу управління професійно-педагогічним самопроєктуванням майбутніх менеджерів освіти; 5) забезпечення реалізації акмеологічної технології управління профресійнопедагогічним самопроєктуванням майбутніх менеджерів освіти.

Вирішення першого і другого завдань забезпечує теоретико-методологічний блок, який включає базисний компонент (сутність профресійно-педагогічного самопроєктування, модель майбутнього менеджера освіти як суб'єкта самопроєктування) та компонент методологічного забезпечення (загальнометодологічні підходи, конкретно-методологічні підходи, методологічні принципи). Технологічний блок (технолого-методичний компонент) являє підставу для вирішення третього та четвертого завдань. У межах цього компонента виявляються шляхи, умови і методи забезпечення профресійнопедагогічного самопроєктування, а також етапи такого процесу, розробляється акмеологічна технологія як засіб управління профресійно-педагогічним самопроєктуванням майбутніх менеджерів освіти, а також система акмеологічної підтримки такого самопроєктування. Реалізаційний блок (реалізаційний компонент) включає: авторську програму управління професійно-педагогічним самопроєктуванням майбутніх менеджерів освіти; срорми і методи реалізації авторської програми; акмеологічну траєкторію управління професійно-педагогічним самопроєктуванням майбутніх менеджерів освіти; апробацію та подальшу реалізацію авторської програми.

Розроблена на акмеологічних засадах модель управління професійно-педагогічним самопроєктуванням майбутнього менеджера освіти становить підставу для створення акмеологічної технології формування здатності до самопроєктування та ії реалізаціі в освітньому процесі (для майбутніх мене- джерів освіти - студентів магістратури) та професійній діяльності (для чинних менеджерів освітніх закладів).

Ключові слова: акмеологічна технологія, загальнометодологічні підходи, конкретнометодологічні підходи, майбутній менеджер освіти, просресійно-педагогічне самопроєктування, методологічні принципи, модель управління самопроєктуванням.

The article is devoted to the urgent problem of training future education managers - their professional and pedagogical self-design. In particular, it is noted that the professional activity of education managers is effective if they are ready to achieve their own professional acme, focus on success, own acmeological technologies of selfdevelopment and self-improvement, which is a part of self-design.

In order to understand the essence of selfdesigning, a control model for this process has been developed, which is a hypothesis of its deployment and the possible results of this process. The goal of the professional-pedagogical self-design management model for future education managers is to ensure the success of this management process.

Achieving the goal involves solving a number of problems: 1) essence of the phenomenon definition "self-design"; 2) analysis of methodological approaches and principles; 3) demonstration of acmeological paths and conditions for selfdesign by future education managers; 4) acmeological technology's elaboration as a method of managing professional pedagogical self-designing for future education managers; 5) ensures the acmeological technology's implementation by management professional pedagogical selfdesign for future education managers.

The solution of the first and second problems provides a theoretical and methodological bloc that includes a basic component (the essence of professional pedagogical self-design, a model for the future education manager as a subject of selfdesign) and a component of methodological support (general methodological approaches, specific methodological approaches, methodological principles). The technological bloc (technological and methodological component) forms the basis for solving the third and fourth problems, within the framework of this component, ways, conditions and methods for ensuring professional and pedagogical self-design, as well as phases of this process are identified, acmeological technology is developed as a method of managing future professional and pedagogical self-design education managers, as well as the acmeological support system for self-designing. The implementation bloc (implementation component) includes: the author's program of professional and pedagogical self-design management for future education managers; forms and methods of implementing the author's program; the acmeological trajectory of managing professional pedagogical self-designing for future education managers; approbation and further implementation of the author's program. The management model for professional and pedagogical self-designing for future education manager developed on acmeological founda- 
tions, which is the basis for creating an acmeological technology for building the ability to selfdesign and implement in the educational process (for future education managers - magistracy students) and professional activities (for existing managers of educational institutions).
Key words: acmeological technology, future education manager, specific methodological approaches, methodological principles, selfdesign management model, general methodological approaches, professional and pedagogical self-design.
Постановка проблеми у загальному вигляді. У XXI столітті невпинно зростає потреба у високоосвічених фрахівцях - майстрах своєї справи, котрі можуть відкрити нове бачення на систему сучасної освіти. Компетентності, усвідомлення проблем, які виникають у процесі професійного зростання, побудови менеджерами ділової кар'єри, становлять підставу для їхнього вдосконалення.

Професійна діяльність менеджерів освіти $€$ ефрективною за умови наявності готовності до досягнення ними власного профресійного акме, націленості на успіх, володіння акмеологічними технологіями саморозвитку та самовдосконалення, складником яких є самопроектування.

Аналіз останніх досліджень і публікацій. Проблемами самопроектування переймаються сучасні науковці-психологи (Н.В. Чепелєва, М.Л. Смульсон, О.В. Зазимко та ін.), які розглядають самопроектування особистості у дискурсивному просторі [9]. О.Є. Остапчук досліджує френомен самореалізації вчителя, умови підготовки вчителя в парадигмі готовності до самовдосконалення і професійної самореалізації [7].

Аналізуючи френомен самопроектування, сучасні науковці вважають, що здатність до нього $€$ системним багаторівневим утворенням, «яке впродовж життя набуває різних змістовних конфрігурацій, проте, його ядерний складник визначається відносно сталим інтегральним корпусом психологічних характеристик особистості, серед яких провідними є: прагнення до саморозвитку, самодетермінація; продуктивна рефрлексія; толерантність до невизначеності; прогресивний характер смисложиттєвих орієнтацій; перспективна орієнтованість індивідуального досвіду особистості» [3]. При цьому чинники розвитку здатності суб'єкта до самопроектування об'єднуються у три умовні групи: мотиваційні, комунікативні, метакогнітивні.

Слід відзначити суттєвий внесок учених-акмеологів, які досліджують самопроектування як інструмент профресійного саморозвитку майбутніх і чинних фрахівців сорери «людина - людина» (А.О. Деркач, Н.В. Кузьміна, С.Д. Пожарський таін.).

Виділення не вирішених раніше частин загальної проблеми. Незважаючи на появу достатньої кількості наукових розробок проблеми самопроектування у структурі професійного саморозвитку та самореалізації сучасного фрахівця, нині ще не досить уваги приділяється технологічним аспектам фрормування здатності до самопроектування у майбутніх фрахівців (особливо у майбутніх менеджерів освіти). Акмеологічна технологія фрор- мування такої здатності має спиратися на відповідну модель управління цим процесом.

Мета статті - розробити та обґрунтувати модель управління професійно-педагогічним самопроектуванням майбутніх менеджерів освіти.

Виклад основного матеріалу. Для того щоб зрозуміти сутність самопроектування, необхідно розробити модель управління цим процесом, що являє собою гіпотезу про його розгортання та можливі результати такого процесу.

Метод моделювання широко використовується багатьма сучасними науками, зокрема, акмеологією, тому що сама модель задає перспективи, цілі, засоби для будь-якої особистості (в нашому дослідженні майбутнього менеджера освіти) для ії прогресивного розвитку [1].

На підставі детального аналізу управлінської діяльності менеджера освіти, а також праць сучасних учених-акмеологів [2; 4; 5; 6; 8] нами розроблена модель управління професійно-педагогічним самопроектуванням майбутніх менеджерів освіти.

Мета моделі управління профресійно-педагогічним самопроектуванням майбутніх менеджерів освіти полягає у забезпеченні успішності управління цим процесом.

Досягнення мети передбачає вирішення низки завдань:

1) визначення сутності френомена «самопроектування»;

2) аналіз методологічних підходів і принципів;

3) виявлення акмеологічних шляхів та умов самопроектування майбутніх менеджерів освіти;

4) розробка акмеологічної технології як засобу управління профресійно-педагогічним самопроектуванням майбутніх менеджерів освіти;

5) забезпечення реалізації акмеологічної технології управління профресійно-педагогічним самопроектуванням майбутніх менеджерів освіти.

Вирішення першого і другого завдань забезпечує теоретико-методологічний блок, який включає базисний компонент (сутність профресійно-педагогічного самопроектування, модель майбутнього менеджера освіти як суб'єкта самопроектування) та компонент методологічного забезпечення (загальнометодологічні підходи, конкретно-методологічні підходи, методологічні принципи).

Самопроектування - процес виявлення можливих варіантів поєднання засобів, цілей, просторово-часових параметрів діяльності 3 метою пошуку найбільш прийнятного, оптимального 
варіанту для розвитку і вдосконалення особистості. Результатом самопроектування є різні проєкти (варіанти) майбутньої діяльності, різні моделі Я-ідеального.

Розглянемо зміст компонента методологічного забезпечення.

Акмеологічний підхід, на думку А.О. Деркача, визначається використанням загальних підходів (комплексного, системного, суб'єктного), загальних принципів (принципу детермінізму, принципу розвитку, принципу гуманізму), а також спеціальних, більш конкретних методологічних принципів (принципу суб'єкта діяльності, принципу життєдіяльності, принципу потенційного й актуального, принципу моделювання, принципу оптимальності, операційно-технологічного принципу, принципу зворотного зв'язку).

Комплексний підхід націлений на інтеграцію знання про різні аспекти, властивості і стани людини і різні системи, в яких вона здійснює свою життєдіяльність. Комплексний підхід в акмеології націлений на інтеграцію різнорівневого знання про закономірності і механізми прогресивного розвитку людини як індивіда, суб'єкта діяльності, особистості та індивідуальності. Специфріка комплексного підходу в акмеології полягає також у тому, що він задає орієнтацію на єдність вивчення і реального вдосконалення людини. Основна ідея комплексного підходу полягає у вивченні об'єкта як цілого, що складається 3 різних взаємопов'язаних елементів, упорядкованого і складно організованого. В акмеології системний підхід уможливлює розкриття змісту прогресивного розвитку особистості та її особистісно профресійного розвитку як акмеологічної системи. Суб'єктний підхід заснований на ідеї С.Л. Рубінштейна про суб'єкт як центр організації буття та суб'єктності, що виявляється через потребу і здатність вдосконалення людини.

Принцип детермінізму: 1) акмеологія розглядає внутрішні умови особистості як спонукальні причини і детермінанти розвитку; 2) системоутворюючим фрактором або рушійною силою розвитку $€$ сама особистість, а механізмом розвитку - саморегуляція, самоорганізація (на відміну від суто зовнішньої регуляції процесу розвитку); 3) процес вдосконалення особистості має подієву детермінацію: внутрішню (розкриття потенціалу) і зовнішню (усвідомлюваних і прийняття зовнішніх впливів). Принцип розвитку розуміється як орієнтація на прогресивний розвиток і самовдосконалення особистості і суспільства. Принцип розвитку передбачає: 1) розуміння розвитку як вдосконалення, руху до зрілості, до оптимального вищого рівня; «руху за висхідною»; 2) визнання суб'єктивного характеру розвитку; 3) здійснення розвитку, через що суб'єктом вирішуються протиріччя; 4) урахування індивідуального характеру розвитку; 5) розгляд розвитку в контексті життєвого шляху і діяльності особистості; 6) зв'язок розвитку особистості як у життєвому плані, так і в професійному; 7) урахування співвідношення потенційного й актуального в розвитку особистості; 8) акмеологія не зіставляє послідовні стадії розвитку, а вивчає наявну стадію порівняно 3 ідеалом, 3 перспективою. Принцип гуманізму полягає в пріоритеті не абстрактних для людини цінностей, а цінностей її власної особистості - здоров'я, оптимізму, працездатності. Принцип суб'єкта діяльності - особливість цього принципу полягає в тому, що, функціонуючи, особистість вписується в інші системи життєдіяльності, зокрема професійну діяльність, спілкування, пізнання. Сутність принципу життєдіяльності дає можливість зрозуміти місце, роль, зміст і значення діяльності в життєвому шляху особистості, зрозуміти життя не тільки як вільний від роботи час, але і як завдання самореалізації особистості. Принцип потенційного й актуального виконує дві функції: 1) методологічного орієнтира на резерви, можливості особистості, які можуть реалізуватися в майбутньому самою особистістю або за акмеологічної підтримки; 2) практико-діагностичного орієнтира. Принцип моделювання був розроблений у середині XXI століття у сорері управління соціальними та виробничими системами. Ідеальна модель включає інтеграл вихідного стану особистості, способу його зміни і розвитку і його фрінішний, кінцевий стан. Операційно-технологічний принцип характеризує сутність акмеології як прикладної, практичної дисципліни. Технології, що застосовуються в акмеології, мають відповідати принципу оптимізації особистісних і професійних ресурсів.

Технологічний блок (технолого-методичний компонент) являє підставу для вирішення третього та четвертого завдань. У межах цього компонента виявляються шляхи, умови і методи забезпечення професійно-педагогічного самопроектування, а також етапи такого процесу, розробляється акмеологічна технологія як засіб управління просресійно-педагогічним самопроектуванням майбутніх менеджерів освіти, а також система акмеологічної підтримки такого самопроектування.

Усвідомлене використання проєктувального підходу в особистості людини, досягнення нею вищого рівня реалізації свого потенціалу - акме обмежене труднощами, пов'язаними зі створенням і впровадженням у практику спеціальних програм і фрорм навчання проєктування, необхідністю зміни шляхів і умов професійно-педагогічного самопроектування, що забезпечують їх реалізацію, а також з відсутністю проєктної компетенції менеджерів або низьким рівнем її розвитку.

Умовами успішного фрормування умінь і навичок самопроектування професійної діяльності під час професійної підготовки менеджерів освіти вважаємо: фрормування і розвиток у майбутніх фрахівців умінь професійного Я, усвідомлення ними зна- 
чущості умінь самопроектування; підвищення ролі самостійної роботи з проєктування; інтегроване застосування активних методів, підходів і принципів, що спеціально націлені на фрормування готовності до самопроектування професійної діяльності.

Формування здатності до самопроектування менеджера буде успішним, якщо буде розроблена та реалізована програма і технологія формування самопроектування менеджера, показниками еорективності якої можуть бути: ціннісно-смислові орієнтації менеджера; акмеологічні компетентності; профресійна готовність менеджера до реалізації акмеологічної технології управління як умови реалізації менеджером індивідуального освітнього маршруту (професійна готовність включає наявність розробленої авторської програми індивідуальної управлінської дії і підтримує реалізацію систематичного акмеологічного самопроектування); організаційно-управлінські умови, що сприяють формуванню здатності до самопроектування менеджера. Під час професійної підготовки необхідно розвивати у майбутніх менеджерів освіти культуру самопроектування.

Успішне освоєння програми «Акмеологічна технологія як засіб управління професійно-педагогічним самопроектуванням майбутніх менеджерів освіти» дасть менеджерам змогу ефективніше здійснювати консультаційну, організаційну та іншу допомогу під час розробки та реалізації індивідуальних освітніх програм, а також забезпечити умови для успішного просування менеджерів за їхніми індивідуальними акмеологічними траєкторіями.

Мета програми - фрормування системи акмеологічних компетенцій, наявність яких забезпечить готовність менеджера до застосування акмеологічної технології в професійній діяльності, в управлінській практиці.

Очікуваними результатами роботи менеджера освіти в управлінському процесі є: 1) компетентність, комплекс компетенцій, які забезпечують готовність і здатність здійснювати самопроектування, самоосвіту і саморозвиток, включаючи профресійне самопроектування і саморозвиток; 2) акмеологічна компетентність, комплекс професійних акмеологічних компетенцій, які забезпечують застосування акмеологічної технології в професійній діяльності, в управлінській практиці; 3) готовність і здатність слухати і чути, розуміти і приймати іншу людину (толерантність); 4) самовизначення; 5) самореалізація; 6) самоосвіта (готовність до освіти протягом усього життя); 7) готовність до життєвого і профресійного вдосконалення.

Реалізаційний блок (реалізаційний компонент) включає: авторську програму управління професійно-педагогічним самопроектуванням майбут- ніх менеджерів освіти; фрорми і методи реалізації авторської програми; акмеологічну траєкторію управління професійно-педагогічним самопроектуванням майбутніх менеджерів освіти; апробацію та подальшу реалізацію авторської програми.

Результат розробленої моделі управління професійно-педагогічним самопроектуванням майбутніх менеджерів освіти - майбутній менеджер освіти як професіонал, який здатний здійснювати успішне управління власним професійним самопроектуванням.

Висновки. Розроблена на акмеологічних засадах модель управління професійно-педагогічним самопроектуванням майбутнього менеджера освіти являє підставу для створення акмеологічної технології фрормування здатності до самопроектування та її реалізації в освітньому процесі (для майбутніх менеджерів освіти - студентів магістратури) та професійній діяльності (для чинних менеджерів освітніх закладів).

\section{БІБЛІОГРАФІЧНИЙ СПИСОК:}

1. Вартофский М. Модели. Репрезентация и научное понимание. / Пер. с англ. Общ. ред. и послесл. И.Б. Новика и В.Н. Садовского. Москва : Прогресс, 1988. 507 c.

2. Гладкова В.М. Профресійне самовдосконалення менеджерів вищих навчальних закладів: акмеологічні основи : монограсрія. Київ : Освіта України, 2013. $350 \mathrm{c}$.

3. Гуцол К.В. Чинники розвитку здатності особистості до самопроектування. URL: http://newlearning.org.ua/sites/default/files/tezy/2018/ Hutsol_Kyrylo_2018.pdf (дата звернення: 04.08.2019).

4. Деркач А.А., Зазыкин В.Г. Методы акмеологических исследований : учебное пособие. Москва : Изд-во РАГС, 2010. 166 с.

5. Кузьмина Н.В., Жаринова Е.Н. Методы исследования образовательных систем : монографияя / Под ред. Н.М. Жаринова. Санкт-Петербург : Изд-во НУ «Центр стратегических исследований», 2018. 164 c.

6. Новська О.Р. Методика самопроектування срахового розвитку студентів магістратури у процесі музичного навчання в педагогічних університетах : дис. ... канд. пед. н. : спец. 13.00.02. Одеса : ПНПУ ім. К.Д. Ушинського, 2015. 247 с.

7. Остапчук О.Є. Самопроектування як засіб профресійної самореалізації майбутнього вчителя. URL: http://ea.donntu.edu.ua/bitstream/123456789/16584/4/ ostapchuk.pdf (дата звернення: 04.08.2019).

8. Фундаментальна акмеологія - наука XXI століття : монографрія / заг. ред. В.М. Гладкової, С.Д. Пожарського. Київ : Інтерсервіс, 2019. 206 с.

9. Чепелєва Н.В. Самопроектування особистості у контексті постнекласичної психології. Наукові записки. Серія «Психологія і педагогіка». 2012. Tом 20. C. 17-25. 